\title{
Gorbachev's candid friend
}

\section{London}

ACADEMICIAN Andrei Sakharov last week warned the West against increasing economic and scientific aid to the Soviet Union. In the absence of radical reforms of the Soviet system, he said, such assistance could serve only to prop up an ailing system and delay the advent of democracy. It would be "pouring water into the sand" to increase assistance at this time.

Sakharov, in Britain to receive honorary degrees from the universities of Sussex and Oxford, delivered his warnings at the Royal Institute of International Affairs. $\mathrm{He}$ described the present situation of the Soviet Union as one of chronic shortage, a bankrupt economy and a national debt that is, per capita, higher than that of any other country in the world.

The current "economic reforms", Sakharov maintained, are not working, since the officials in charge of implementing them have no real authority or independence. At the same time, there is an increase of political awareness, which culminated in the run-up to the elections to the Congress of People's Deputies, and a growing ethnic consciousness of the nonRussian peoples of the Soviet Union.

"Our state is the last empire in the world", Sakharov said, adding that if the ethnic problems are not solved in a "constitutional, rational way", civil war or a right-wing coup could well ensue.

The ethnic problem, Sakharov said, overlaps with that of the environment, since the central planners in Moscow have imposed disastrous decisions in conditions of which they had no knowledge. He cited the notorious case of Uzbekistan, where a cotton monoculture has been forced on the population.

The Uzbeks, Sakharov said, are compelled to grow cotton even on their private allotments. Workers in the cotton-fields - for the most part, students and children who lose up to two months study each year - are poisoned with pesticides and defoliants so that the majority of national servicemen from Uzbekistan are unfit for the army.

To deal with this and similar problems, Sakharov said, radical reforms are needed. The problems of the Uzbekistan cotton fields have, in fact, been wellknown to Western observers for years. Sakharov, however, spoke of them with all the intensity of one newly aware of the situation. But, as he explained, one of the most important achievements of the Congress of People's Deputies was to make delegates, and through them the Soviet public, aware of just how bad the economic and political situation in the Soviet Union really is.

Under such circumstances, Sakharov was reluctant to give a prognosis. The
Soviet Union, he said, had reached a turning point, and there was no certainty which way it would go - towards hardline conservatism, or towards greater reform. His view of Mikhail Gorbachev seemed ambivalent; he praised the Soviet leader's current stance, yet, at the same time, emphasized that he had come to power as a result of agreements within the Central Committee of which the Soviet public still know very little.

Gorbachev, he said, had changed the constitution in order to reach a position of power without the necessity of election. Sakharov praised him for perestroika, but was plainly worried that Gorbachev might find it simpler to exercise the power in his hands than to deal with the problems around him. But Sakharov acknowledged that he is the only leader in sight.

Vera Rich

\section{. \\ US forecast too low?}

\section{Washington}

THE US Centers for Disease Control (CDC) underestimated the number of AIDS cases the United States can expect by the end of 1991 by as much as onethird, according to a report released this week by the US General Accounting Office $(\mathrm{GAO})$. The GAO says the $195,000-320,000$ cases projected by CDC is too low, and that a figure of between 300,000 and 485,000 is closer to the mark.

The GAO scrutinized 13 different forecasts of the AIDS epidemic and found serious errors in the underlying data on which the projections were based. Delays in the reporting of cases to CDC by local health departments, and the exclusion of many AIDS cases before the definition of the disease was broadened in 1987 , were cited as the principal problems. The agency also found that AIDS cases arising from heterosexual contact were less likely to be accurately reported, and that in many forecasts heterosexual intercourse was simply assumed not to be the cause of AIDS infection if other risk factors, such as drug use, were also present.

To come up with better estimates of the spread of HIV infection, GAO recommends that the US Secretary for Health and Human Services, Louis W. Sullivan, should authorize further studies into the biases of AIDS case reporting, and examine whether CDC needs more resources to do the job. GAO also supports a nationwide assessment of risk behaviours, such as the survey of sex practices proposed by the National Institutes of Health.

\section{Future still vague for new venture}

\section{London}

THE need for international collaboration in the research effort to understand global environmental problems was stressed by Kenneth Baker, the British Secretary of State for Education and Science, opening the first plenary session of the Academia Europaea (AE) in London on Monday.

On the pretext that an overview of British science policy would be to the general enlightenment of a body comprising over 600 senior academics representing the Academies of Arts and Sciences of $\mathbf{2 0}$ countries, Baker took the opportunity to re-iterate the often controversial science policy objectives espoused by the 10-yearold government of Prime Minister Margaret Thatcher.

The AE itself was conceived as a supranational version of the Royal Society which, with the British Academy, has so far been the focus of the Academia's initiatives. The idea of an Academy covering science and humanities in Europe, was developed by a group of scholars meeting at the Royal Society in 1985. But the AE came into existence only in September last year when the 100 or so invited 'Foundation Members' met at Cambridge.

Renewable resources and human origins were on the agenda at the London meeting this week, but arrangements for the next meeting, in Strasbourg next year, are not yet finalized. Neither, it seems, are the detailed objectives of the AE, except that it will concern itself with research issues of relevance to the entire continent "from the Urals to the Bosporus", in the words of $\mathrm{AE}$ President, Sir Arnold Burgen of the University of Cambridge. Higher education and East-West relations will be high on the list of priorities.

Henry Gee

THINK TANK

\section{Academy to leave Berlin \\ Munich}

THE two-year-old Academy of Science and Technology in Berlin will definitely have to leave the city, after a resolution to close it was introduced last week in the West Berlin Senate. The academy was founded in $\mathbf{1 9 8 7}$ by a Christian Democratic government as a think tank for issues concerning technology and society, but was derided by opposition Greens and Social Democrats as an "old men's debating club". Meanwhile, the Land of Hesse has offered to pay the DM8 million operating costs of the academy should it wish to move there, probably to the Frankfurt area.

Academy spokesman Eberhard Vogt expects the closure resolution to pass this September and says that the moving date of January 1990 offered by Hesse is "realistic". 